Dipublikasikan

Badan Pelaksana Kuliah Kerja Nyata

Universitas Lampung

Sekretariat Badan Pelaksana Kuliah Kerja Nyata, Universitas Lampung, J. Prof. Dr. Soemantri Brojonegoro No. 1, Bandar Lampung 35145.

\title{
SOSIALISASI PENCEGAHAN COVID-19 DAN PERILAKU HIDUP BERSIH DAN SEHAT (PHBS) DESA WIYONO KECAMATAN GEDONGTATAAN KABUPATEN PESAWARAN
}

\author{
Sapto Kuncoro ${ }^{1}$, Abie Perdana Kusuma ${ }^{2}$, Aura Priscilla Sabatini ${ }^{2}$, Ajeng Diah \\ Amanda $^{2}$, Adhanis Tya Garnis ${ }^{2}$, Abdul Aziz ${ }^{2}$, Feriza Yolanda Putri², Eva Selviana ${ }^{2}$, \\ Juliana Puspita Sari², Monica Karnailia' ${ }^{2}$, Nindya Aisah Indriyani², Ratih Indah \\ Wardani $^{2}$, Valen Miranda ${ }^{2}$ \\ ${ }^{1}$ Program Studi Teknik Pertanian/FP, Universitas Lampung. \\ ${ }^{2}$ Mahasiswa KKN Periode II 2021 Universitas Lampung
}

Penulis Korespodensi : eva.selviana1075@students.unila.ac.id

\begin{abstract}
Abstrak
Penyebaran Covid-19 atau Corona Virus Disease 2019 kini telah menjadi pandemi. Virus ini menyerang bagian pernafasan bagi para penderitanya. Artikel ini berupaya memberikan gambaran dan penjelasan terkait program kerja sosialisasi covid-19, sosialisasi perilaku hidup bersih dan sehat (PHBS), pembagian handsanitizer dan sabun cuci tangan yang meliputi proses, hasil dan manfaatnya. Penulisan artikel ini menggunakan pendekatan kualitatif dengan metode deskriptif-eksplanatif. Hasilnya, masyarakat menerima pemahaman dan wawasan baru terkait penyakit covid-19 dan pentingnya perilaku hidup sehat salah satunya dengan cara mencuci tangan serta masyarakat mampu membuat sabun cuci tangan sendiri. Artikel ini terbatas pada pelaksanaan KKN Mandiri Putra Daerah Periode 2021
\end{abstract}

Kata kunci: covid-19, PHBS, sabun.

\section{Abstract}

The spread of Covid-19 or Corona Virus Disease 2019 has now become a pandemic. This virus attacks the respiratory tract for sufferers. This article seeks to provide an overview and explanation regarding the COVID19 socialization work program, socialization of clean and healthy living behavior (PHBS), distribution of hand sanitizer and hand washing soap which includes the process, results and benefits. The writing of this article uses a qualitative approach with a descriptive-explanative method. As a result, the community received new understanding and insight regarding the COVID-19 disease and the importance of healthy living behavior, one of which was by washing hands and the community was able to make their own handwashing soap. This article is limited to the implementation of KKN Mandiri Putra Region 22021.

Keywords: covid-19, PHBS, soap. 


\section{Jurnal Pengabdian Kepada Masyarakat BUGUH}

Dipublikasikan

Badan Pelaksana Kuliah Kerja Nyata

Universitas Lampung

Sekretariat Badan Pelaksana Kuliah Kerja Nyata, Universitas Lampung

J. Prof. Dr. Soemantri Brojonegoro No. 1, Bandar Lampung 35145.

\section{Pendahuluan}

Penyebaran Covid-19 atau Corona Virus Disease 2019 kini telah menjadi wabah pandemic di Indonesia. Mewabahnya penyebaran penyakit ini menyebabkan bencana bagi masyarakat hingga mengakibatkan kematian ribuan jiwa di seluruh dunia, tak terkecuali di Indonesia. Covid-19 atau Corona Virus Disease 2019 sendiri merupakan wabah penyakit yang menyebar hingga ke seluruh dunia. Virus yang menyebabkan penyakit ini yaitu Serve Acute Respiratory Syndrome Coronavirus 2 (SARS-CoV-2). Virus ini menyerang bagian pernafasan bagi para penderitanya. Penyakit ini dapat menular dengan berbagai cara seperti melalui percikan saat batuk, bersin, atau berbicara, melalui kontak langsung, dan juga melalui benda di sekitar kita. Saat tertular penyakit ini biasanya seseorang mengalami beberapa gejala yaitu batuk, nyeri tenggorokan, demam dengan suhu tinggi $\left(>38^{\circ} \mathrm{C}\right)$, sesak napas, dan flu yang disertai hidung tersumbat (corona.jakarta.go.id).

Perubahan sikap diperlukan dari setiap individu dalam hal menjaga kesehatan tubuhnya saat menghadapi wabah Covid-19 ini. Mengubah kebiasaan negative menjadi kebiasaan yang berdampak positif bagi dirinya sendiri sangat membantu dalam meminimalisir penularan wabah penyakit ini. Salah satu metode yang dianjurkan dengan menerapkan Perilaku Hidup Bersih dan Sehat (PHBS). Menurut Kementrian Kesehatan tahun 2015, PHBS merupakan perilaku kesehatan yang dilakukan oleh kesadaran diri sendiri, sehingga dapat menularkan kebiasaan yang positif kepada keluarga dan juga lingkungan masyarakat.

Ada beberapa kegiatan yang mencerminkan pada Perilaku Hidup Bersih dan Sehat (PHBS) yang dapat mencegah penularan Covid-19 yaitu mengkonsumsi makanan bergizi seimbang, istirahat cukup, sering mencuci tangan dengan sabun di air mengalir, olahraga atau akivitas fisik, tidak merokok, dan menjaga kebersihan lingkungan.

Agar kasus Covid-19 ini tidak terus mengalami kenaikan, perlu adanya langkah pencegahan yaitu dengan menerapkan Perilaku Hidup Bersih dan Sehat (PHBS). Hal ini dapat dimulai dengan melakukan sosialisasi mengenai cara pencegahan covid-19 maupun cara penerapan dalam melaksanakan PHBS. Seperti cara mencuci tangan yang tepat di air mengalir mengggunakan sabun cuci tangan maupun penggunaan handsanitzer sebagai pengganti sabun cuci tangan ketika berada di lingkungan yang minim terdapat air.

\section{Bahan dan Metode}

Pembuatan sabun cair cuci tangan dilaksanakan pada tanggal 29 Agustus 2021 di Desa Wiyono, Kecamatan Gedong Tataan, Kabupaten Pesawaran.

Adapun bahan yang digunakan yaitu air bersih, texapon, garam dapur, antiseptik, pewangi, dan pewarna makanan. Sedangkan peralatan yang digunakan yaitu wadah bersih, botol kecil, dan sendok. Kegiatan penyuluhan dan pelatihan pembuatan sabun cair cuci tangan dilaksanakan dengan melibatkan Kelompok Pemberdayaan Masyarakat (POKDAMA) setempat, yaitu Kelompok Wanita Tani (KWT) menggunakan metode berikut ini:

a. Pelatihan Pembuatan Sabun Cair Cuci Tangan secara langsung

Kegiatan utama yaitu berupa percobaan atau pembuatan sabun cair cuci tangan yang dilaksanakan di Balai Desa Wiyono.

b. Sosialisasi

Sosialisasi dilaksanakan pada tanggal 29 Agustus 2021 yang bertujuan untuk membentuk perilaku hidup bersih dan sehat, salah satunya dengan pemanfaatan sabun cair cuci tangan tersebut. 
Dipublikasikan

Badan Pelaksana Kuliah Kerja Nyata

Universitas Lampung

Sekretariat Badan Pelaksana Kuliah Kerja Nyata, Universitas Lampung,

J. Prof. Dr. Soemantri Brojonegoro No. 1, Bandar Lampung 35145.

\section{Hasil dan Pembahasan}

\section{a. Pembuatan Sabun Cair Cuci Tangan}

Kegiatan ini dikatakan berhasil karena dapat dilihat dari antusias dan partisipasi dari ibu-ibu KWT dan beberapa ibu-ibu masyarakat Dusun Wiyono yang hadir dalam rangkaian kegiatan Sosialisasi Pencegahan Covid-19 dan Sosialisasi Perilaku Hidup Bersih dan Sehat (PHBS).

Pada kegiatan ini yang pertama dilakukan adalah pembukaan acara kegiatan, sambutan dari perwakilan mahasiswa KKN Universitas Lampung, dan sambutan Kepala Desa Wiyono. Kemudian dilanjutkan dengan sosialisasi tentang pentingnya cara pencegahan Covid-19, serta dilanjutkan dengan sosialisasi tentang PHBS yang disampaikan oleh mahasiswa KKNUniversitas Lampung. Sosialisasitersebut dilakukan untuk menghimbau kepada masyarakat khususnya kepada ibu-ibu KWT dan beberapa ibu-ibu masyarakat Dusun Wiyonoyang hadir terhadap pentingnya menjaga kesehatan terutama dimasa pendemi inidan diharapkan masyarakat Desa Wiyono dapat menerapkan perilaku hidup bersih dan sehat dalam kehidupan sehari-hari.

Materi untuk sosialisasi covid-19 yang disampaikan adalah tentang morfologi virus, gejala yang di derita oleh pasien dan pentingnya vaksinasi bagi masyarakat luas.Salah satu yang mendasari diadakannya sosialisasi ini ialah karena kurangnya pemahaman tentang covid-19 dan banyaknya rumor tentang vaksin jika vaksin itu adalah suatu hal yang tidak baik dan memiliki banyak efek samping.Namun, berkat adanya sosialisasi covid-19 ini banyak ibu-ibu yang tadinya takut untuk di vaksin menjadi berani untuk mendapatkan vaksin.Kemudian untuk Materi Perilaku Hidup Bersih dan Sehat (PHBS) yang disampaikan adalah tentang pengertian dari PHBS, hakikat dari perilaku, contoh dari permasalahan yang bisa disebabkan karena tidak menerapkan PBHS di lingkungan rumah tangga serta hal-hal yang harus dilakukan untuk urusan rumah tangga.

Praktik pembuatan sabun cair cuci tangan dilakukan pada sesi sosialisasi PHBS.Sabun cair cuci tangan ini merupakan salah satu cara untuk mewujudkan perilaku hidup bersih dan sehat.Adapun tata cara dalam pembuatan sabun cair cuci tangan sebagai berikut:

1. Pertama siapkan wadah bersih seperti ember atau baskom, setelah itu masukkan air bersih dengan takaran $500 \mathrm{ml}$ ke dalam wadah tersebut.

2. Tambahkan 3 sendok makan texapon kedalam air kemudian aduk terus sampai air dan texapon tercampur rata.

3. Kemudian tambahkan garam dapur secukupnya dan aduk terus hingga campuran tersebut mengental.

4. Apabila campuran sudah mengental tambahkan antiseptik untuk anti bakteri dan aduk lagi hingga tercampur. Dapat menggunakan detol cair atau antiseptik cair yang sejenisnya.

5. Setelah itu tambahkan pewarna makanan sedikit saja dan aduk hingga warna tercampur sehingga sabun memiliki warna yang khas.

6. Terakhir tambahkan pewangi secukupnya dan aduk hingga tercampur.

7. Setelah tercampur semua letakkan ditempat yang aman dan diamkan semalaman agar buihbuih sabun menghilang.

8. Apabila buih-buih sabun yang ada dipermukaan sudah menghilang semua, masukkan sabun ke dalam botol yang sudah disiapkan dan sabun sudah siap untuk dibagikan.

Dalam kegiatan ini kami juga memberi tahu bagaimana cara mencuci tangan yang benar? Ada lima langkah sederhana yang bisa dilakukan, yaitu:

1. Basahi tangan dengan air bersih yang mengalir (hangat atau dingin), matikan keran, dan gunakan sabun cuci tangan.

2. Gosok kedua tangan menggunakan sabun hingga berbusa. Gosok sampai berbusa bagian telapak tangan, punggung tangan, di sela-sela jari, dan di bawah kuku. 
Dipublikasikan

Badan Pelaksana Kuliah Kerja Nyata Universitas Lampung

Sekretariat Badan Pelaksana Kuliah Kerja Nyata, Universitas Lampung, J. Prof. Dr. Soemantri Brojonegoro No. 1, Bandar Lampung 35145.

3. Gosoklah tangan setidaknya selama 20 detik.

4. Lalu, bilastangan dengan benar di bawah air bersih yang mengalir.

5. Terakhir, keringkantangan menggunakan handuk bersih.

Di tengah pandemi Covid-19, sebaiknya harus rutin mencuci tangan. Selain menggunakan masker dan menjaga jarak, mencuci tangan menjadi cara yang efektif untuk mencegah penularan virus corona.

\section{b. Kelebihan dan Kelemahan}

Kelebihan dari kegiatan sosialisasi covid-19 dan sosialisasi PHBS bagi masyarakat dan ibu-ibu KWT adalah dengan adanya acara sosialisasi ini mereka bisa mendapatkan pengetahuan lebih lanjut terkait dengan corona virus yang sedang marak menginfeksi banyak manusia dimuka bumi ini, selain itu juga bisa mendapatkan pengetahuan tentang bagimana cara hidup sehat agar terhindar dari berbagai penyakit baik dari faktor luar maupun dari dalam tubuh diri sendiri dengan menerapkan materi yang telah di berikan pada saat sosialisasi. Kelebihan dari pembuatan sabun cuci tangan adalah agar masyarakat dapat membuat sabun sendiri karena bahan yang diperlukan sangat mudah didapat dan juga karena pembuatannya yang sangat mudah.

Adapun kelemahan dari acara ini adalah pemateri yang memberikan materi masih tergolong baru dalam hal terkait covid-19 dan PHBS sehingga tidak terlalu maksimal dalam menyampaikan materi untuk sosialisasi dan kelemahan dalam demonstrasi sabun adalah saat selesai pembuatan sabun hasil akhir harus menunggu selama sehari untuk menghilangan buihnya sehingga sabun yang dibuat saat demonstasi belum sempurna sepenuhnya.

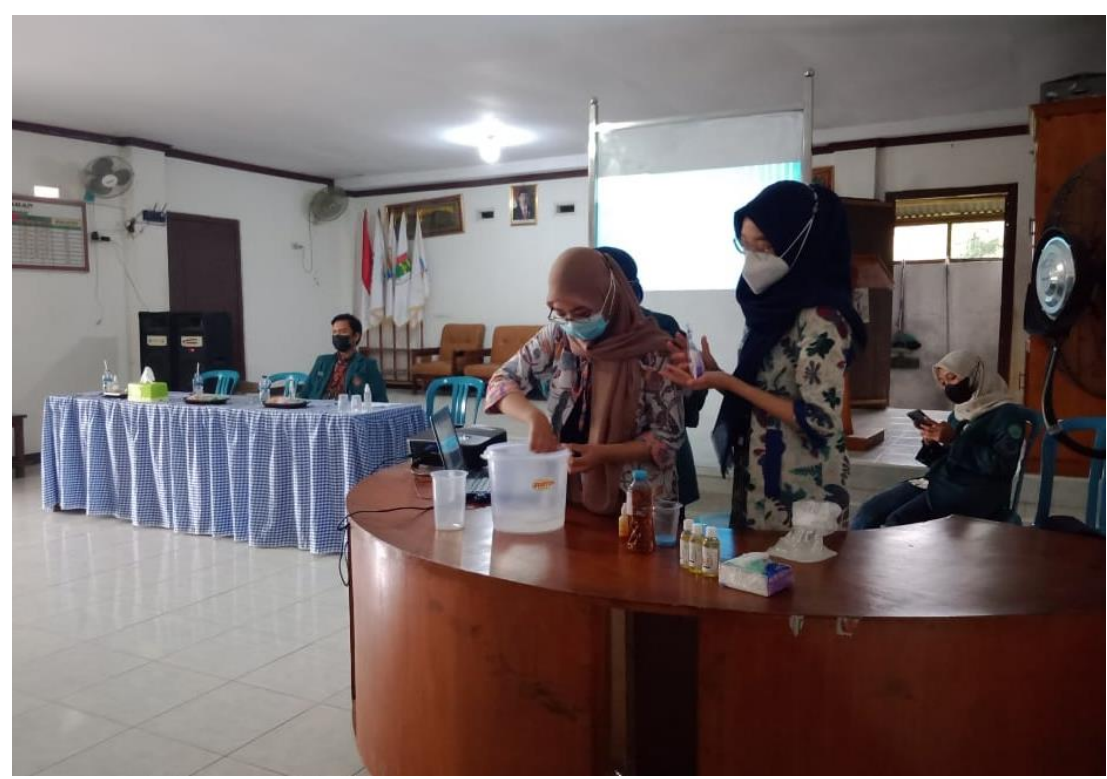

Gambar 1. Pembuatan Sabun Cair Cuci Tangan 
Dipublikasikan

Badan Pelaksana Kuliah Kerja Nyata Universitas Lampung

Sekretariat Badan Pelaksana Kuliah Kerja Nyata, Universitas Lampung, J. Prof. Dr. Soemantri Brojonegoro No. 1, Bandar Lampung 35145.

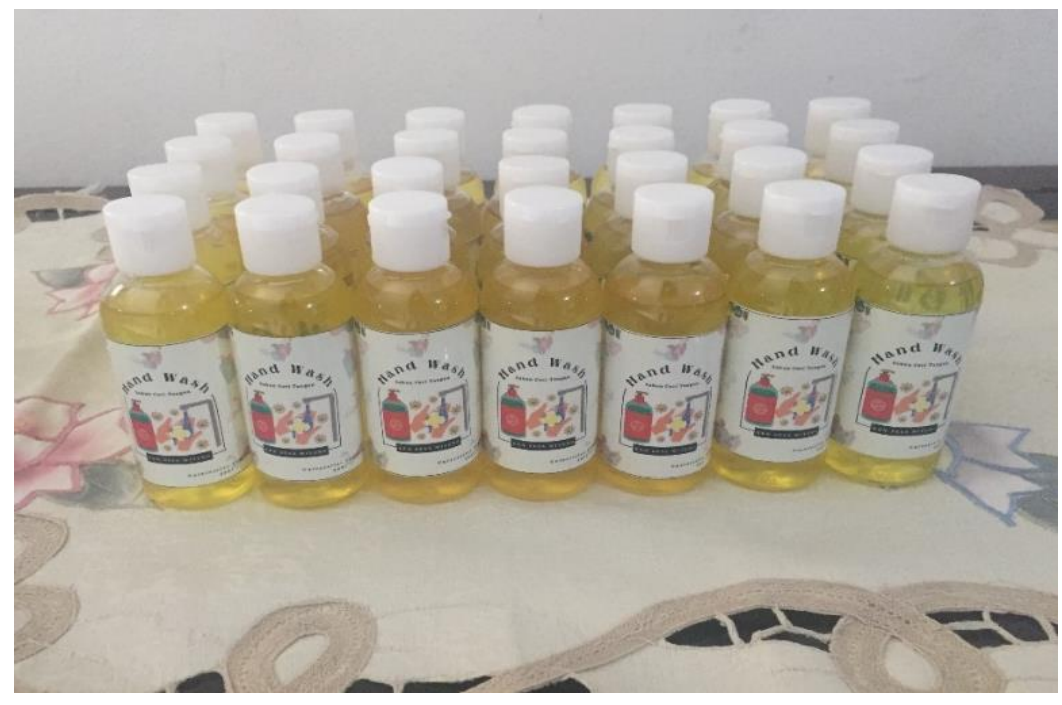

Gambar 1. Produk Sabun Cuci Tangan

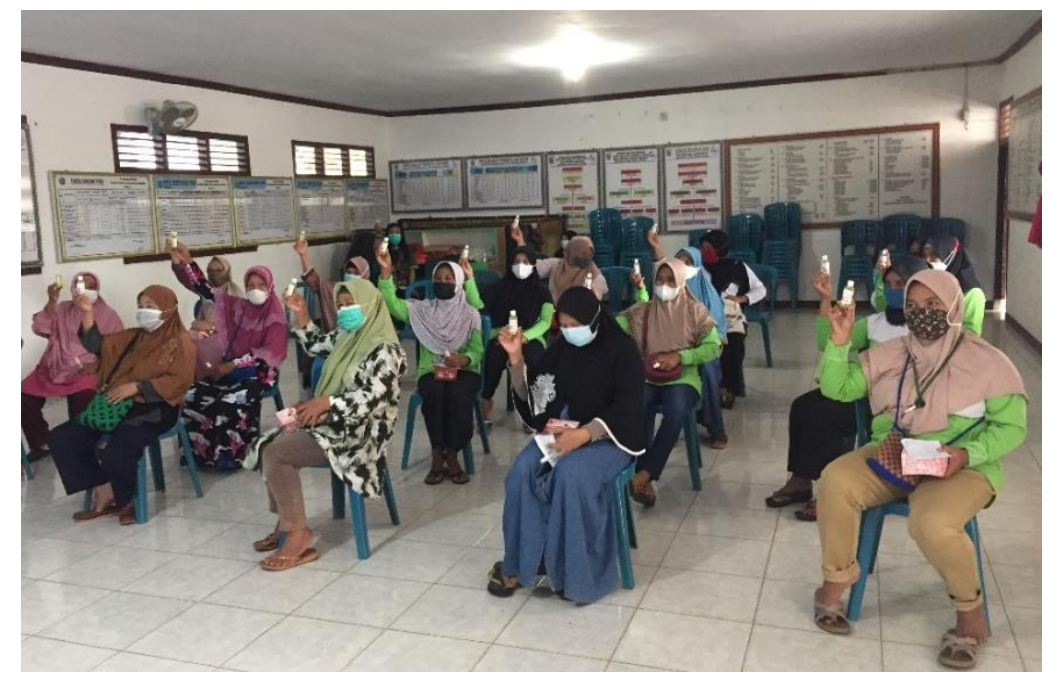

Gambar 2.Pembagian Sabun Cair Cuci Tangan

Tabel 1. Keadaan awal dan keadaan akhir yang diharapkan dari peserta sosialisasi

No

Keadaan Awal

Perlakuan

Keadaan Akhir

1) Masyarakat jarang menerapkan perilaku hidup bersih dan sehat sesuai dan kurang menyadari pentingnya mencegah diri dari virus Covid-19.
Pemberian materi tentang Perilaku Hidup Bersih dan Sehat serta materi tentang covid-19 dan pencegahannya.
Peserta sosialisasi dapat memahami dan menerapkan perilaku hidup bersih dan sehat dalam masyarakat serta mengetahui bahaya covid-19 sekaligus pencegahannya. 


\section{Jurnal Pengabdian Kepada Masyarakat BUGUH}

Dipublikasikan

Badan Pelaksana Kuliah Kerja Nyata Universitas Lampung

Sekretariat Badan Pelaksana Kuliah Kerja Nyata, Universitas Lampung J. Prof. Dr. Soemantri Brojonegoro No. 1, Bandar Lampung 35145.

2) Masyarakat khususnya yang ikut dalam sosialisasi belum mengetahui pembuatan sabun cuci tangan yang sederhana dan mudah dilakukan.
Praktik pembuatan sabun cuci tangan.

\section{Sumber: Hasil Diskusi dengan Staff Desa Wiyono}

\section{Pembahasan}

Covid-19 atau Corona Virus Disease 2019 merupakan wabah penyakit yang menyebar hingga ke seluruh dunia. Virus yang menyebabkan penyakit ini yaitu Serve Acute Respiratory Syndrome Coronavirus 2 (SARS-CoV-2). Virus ini menyerang bagian pernafasan bagi para penderitanya. Penyakit ini dapat menular dengan berbagai cara seperti melalui percikan saat batuk, bersin, atau berbicara, melalui kontak langsung, dan juga melalui benda di sekitar kita. Saat tertular penyakit ini biasanya seseorang mengalami beberapa gejala yaitu batuk, nyeri tenggorokan, demam dengan suhu tinggi $\left(>38^{\circ} \mathrm{C}\right)$, sesak napas, dan flu yang disertai hidung tersumbat. Coronavirus adalah keluarga besar zoonosis. Virus ini berasal dari hewan yang dapat menimbulkan penyakit dari hewan ke manusia dan kini telah menular dari manusia ke manusia. Virus corona dapat menimbulkan beberapa gejala, yaitu infeksi saluran pernapasan mulai dari influenza biasa hingga penyakit kronis. Separate Respiratory Syndrome in the Middle East (MERS) and Acute Respiratory Syndrome (SARS). Teridentifikasi bahwa COVID-19 jarang mengakibatkan hidung tersumbat, bersin, atau sakit tenggorokan, gejala ini hanya terjadi pada sekitar 5\% penderita3 . COVID-19 dapat ditularkan melalui tetesan (percikan) saat berkomunikasi, batuk dan bersin dari individu yang terindikasi virus Corona dan juga tempat umum atau benda yang telah terkena percikan air liur orang yang terinfeksi selama jangka waktu tertentu (Zukmadini, 2020).

Dalam mencegah penyebaran Covid-19, maka diperlukan adanya penerapan Perilaku Hidup Bersih dan Sehat (PHBS) di lingkungan masyarakat. Penerapan PHBS di masyarakat merupakan tanggung jawab setiap orang yang juga menjadi tanggung jawab pemerintah beserta jajaran sektor terkait untuk memfasilitasi kegiatan PHBS di masyarakat agar dapat dijalankan secara efektif. Selain dari itu, kesadaran bersama untuk melakukan pencegahan penyebaran virus Covid-19 juga menjadi prioritas utama masyarakat dan pemerintah saat ini. Dengan adanya sosialisasi, informasi keduanya diharapkan dapat dipahami dan diterapkan oleh masyarakat Desa Wiyono, Kecamatan Gedongtataan, Kabupaten Pesawaran.

\section{Kesimpulan}

Berdasarkan hasil pembahasan dari pelaksanaan Sosialisasi Covid-19, Sosialisasi Perilaku Hidup Bersih Dan Sehat (PHBS), dan Pembuatan serta pembagian sabun cair cuci tangan secara gratis yang telah dilakukan, maka dapat disimpulkan bahwa:

1. Sosialisasi dan pelatihan pembuatan sabun cair cuci tangan dilaksanakan pada tanggal 29 Agustus 2021 di Balai Desa Wiyono, Kecamatan Gedong Tataan, Kabupaten Pesawaran.

2. Kegiatan ini dilaksanakan dengan melibatkan Kelompok Pemberdayaan Masyarakat (POKDAMA) setempat, yaitu Kelompok Wanita Tani (KWT).

3. Pada kegiatan ini yang pertama dilakukan adalah pembukaan acara kegiatan, sambutan dari perwakilan mahasiswa KKN Universitas Lampung, dan sambutan Kepala Desa Wiyono. Kemudian dilanjutkan dengan sosialisasi tentang pentingnya cara pencegahan Covid-19, serta dilanjutkan dengan sosialisasi tentang PHBS yang disampaikan oleh mahasiswa KKN Universitas Lampung. Sosialisasi tersebut dilakukan untuk menghimbau kepada masyarakat 


\section{BUGUH}

Dipublikasikan

Badan Pelaksana Kuliah Kerja Nyata

Universitas Lampung

Sekretariat Badan Pelaksana Kuliah Kerja Nyata, Universitas Lampung,

J. Prof. Dr. Soemantri Brojonegoro No. 1, Bandar Lampung 35145.

khususnya kepada ibu-ibu KWT dan beberapa ibu-ibu masyarakat Dusun Wiyono yang hadir terhadap pentingnya menjaga kesehatan terutama dimasa pendemi ini dan diharapkan masyarakat Desa Wiyono dapat menerapkan perilaku hidup bersih dan sehat dalam kehidupan sehari-hari.

4. Kegiatan inidikatakan berhasil, karena dapat dilihat dari antusias dan partisipasi dari ibu-ibu KWT dan beberapa ibu-ibu masyarakat Dusun Wiyono yang hadir dalam rangkaian kegiatan Sosialisasi Pencegahan Covid-19 dan Sosialisasi Perilaku Hidup Bersih dan Sehat (PHBS).

\section{Ucapan Terima Kasih}

Puji syukur kepada Allah SWT yang senantiasa kami panjatkan karena hanya dengan rahmat dan hidayah-Nya kami dapat menyelesaikan pengabdian ini. Kami juga banyak mendapatkan dukungan dari berbagai pihak yang telah menyumbangkan pikiran, waktu, tenaga, dan sebagainya. Oleh karena itu, pada kesempatan yang baik ini kami mengucapkan terima kasih kepada:

a) Universitas Lampung

b) BPKKN Universitas Lampung

c) Dosen KDPL Mahasiswa Universitas Lampung

d) Dosen DPL Mahasiswa Universitas Lampung

e) Kepala Desa Wiyono Kec. Gedongtataan Pesawaran

f) Masyarakat Desa Wiyono Kec. Gedongtataan Pesawaran

Semoga amal dan kebaikan yang diberikan kepada kami akan mendapatkan balasan dari Allah SWT. Aamiin.

\section{Daftar Pustaka}

Alia, E. C. (2020). Perilaku Hidup Bersih dan Sehat (PHBS) dalam Pencegahan Covid-19. Jurnal Medika Malahayati, 4(4).

Kementerian Kesehatan. (2016). PHBS. https://promkes.kemkes.go.id/phbs. Diakses pada 24 September 2021.

Layanan Darurat Covid. (2021). Wujudkan Jakarta Sehat, Aman, dan Produktif Jakarta Tanggap Covid-19. https://corona.jakarta.go.id/id. Diakses pada 24 September 2021.

Makarim, R.F. (2020). Lebih Baik Cuci Tangan dengan Sabun Khusus atau Sabun Mandi?. https://www.halodoc.com/artikel/lebih-baik-cuci-tangan-dengan-sabun-khusus-atau-sabunmandi. Diakses pada 28 September 2021.

Malik, F. (2020). Edukasi Perilaku Hidup Bersih dan Sehat (PHBS), Gerakan Menggunakan Masker (Gemas), serta Penggunaan Antiseptik dan Desinfektan Di Desa La Nipa Nipa, Kecamatan Katoi, Kolaka Utara, Provinsi Sulawesi Tenggara.

Utami,F. A., \& Sani, F. (2021). Gambaran Perilaku Hidup Bersih dan Sehat (PHBS) di Era Pandemi Corona Virus Disease (COVID-19) di Indonesia. Bikfokes. Vol. 1.

WHO. (2021). WHO Coronavirus (COVID-19) Dashboard. https://covid19.who.int/. Diakses pada 24 September 2021.

Zukmadini, A.Y. (2020). Edukasi Perilaku Hidup Bersih Dan Sehat (Phbs) dalam Pencegahan Covid-19 kepada Anak-Anak di Panti Asuhan. Jurnal Pengabdi Magister Pendidik Ipa, 3(1). 